\title{
Tofu wastewater treatment using vetiver grass (Vetiveria zizanioides) and zeliac
}

\author{
Romi Seroja ${ }^{1} \cdot$ Hefni Effendi ${ }^{2}$. Sigid Hariyadi ${ }^{1}$
}

Received: 8 May 2017 / Accepted: 16 November 2017 / Published online: 22 January 2018

(c) The Author(s) 2018. This article is an open access publication

\begin{abstract}
Tofu production is a domestic industry, that most of it has no appropriate wastewater treatment facilities. Wastewater of tofu contains high organic matter which can decrease the water quality. This study aimed to analyze capability of Vetiveria zizanioides, $\mathrm{L}$ and zeliac in treating tofu wastewater industry. Zeliac is a new adsorbent, which consists of zeolite, activated carbon, limestone, rice husk ash and cement. Response surface methodology was applied to analyze the data, using central composite design with two factors, i.e., time ( 3,9 , and 15 days) and waste concentration $(20,40$, and $60 \%)$. The optimum treatment occurred at the time of 15 days and $38.41 \%$ of tofu wastewater concentration decreasing up to $76 \%$ of COD, $71.78 \%$ of BOD, and $75.28 \%$ of TSS.
\end{abstract}

Keywords Phytoremediation · Vetiveria zizanioides $\cdot$ Wastewater $\cdot$ Tofu $\cdot$ Zeliac

\section{Introduction}

Industrial activity of tofu in Indonesia is mostly domestic industries; most industries do not have a waste treatment facility. Until now, nearly all tofu factories do not perform a good waste management. Tofu wastewater contains organic substances that can cause the rapid growth of microbes in the water. The COD and BOD of wastewater from tofu processing facilities in Banda Aceh were ranging from 5000 to 8500 and from 3500 to $4500 \mathrm{mg} / \mathrm{L}$, respectively. Those high concentrations of organic compounds can cause bad odours, pollution of the surface, ground water, and river (Faisal et al. 2015). This can lead to decrease in oxygen levels. In addition, Tofu wastewater contains suspended substances as well, resulting in turbidity. Some attempts have been conducted to reduce levels of organic matter in the industrial tofu wastewater, such as the use of physical-chemical methods (Saryanaran et al. 2004) and biological aerobic methods (Tay 1990). However, the application of the method is relatively difficult. This is due to the large amount of coagulant

Hefni Effendi

hefni_effendi@yahoo.com

1 Department of Aquatic Resources Management, Bogor Agricultural University, Bogor, Indonesia

2 Center for Environmental Research, Bogor Agricultural University, Bogor, Indonesia required, the operation is relatively complex, high cost of electricity for aeration, high production of sludge or biomass, and requires a large area.

Phytoremediation is a way to remove contaminants using the plant. Selection of appropriate plant is one important factor in implementing phytoremediation. Effendi et al. (2015b) state that phytoremediation has many advantages compared to other techniques because it can be done with minimal environmental disruption. This technique is widely applied in Asia, America, and Europe (Whitney et al. 2003) in dealing with environmental pollution, especially water pollution. Some types of plants that play an important role in waste treatment, are spinach (Effendi et al. 2015d), lettuce (Effendi et al. 2017; Purwandari et al. 2017; Wahyuningsih et al. 2015), and vetiver grass (Danh et al. 2009; Effendi et al. 2015a).

Vetiver grass ( $V$. zizanioides) has been utilized for waste treatment activities in the polluted environment. V. zizanioides constitutes a quite strong resistance plant and not easy to die and has a heavy fiber and long roots that allow much more uptake of pollutants and provide a convenient condition for aerobic bacteria to develop naturally. Therefore the process of organic substance decomposition presumably lasts more effective than any other plants. Some studies suggest that $V$. zizanioides is used for the processing of organic wastewater from tapioca factory (Indrayatie et al. 2013), study using vetiver plantlets on floating platform with 
aeration to degrade phenol in illegally dumped industrial wastewater (Phenrat et al. 2017), total organic pollution and tetracycline waste (Datta et al. 2013), as well as organic waste with floating wetlands (Chua et al. 2012). In addition, $V$. zizanioides and tilapia have an excellent performance when they are cultivated with aquaponics system (Effendi et al. 2015a). V. zizanioides also has a high economic value, such as the unique craft materials (Tripathy et al. 2014), the raw material of cosmetics and perfumes (Bhatia et al. 2008).

Use of the adsorbent is an alternative method of waste treatment. This method is effective and inexpensive. The most widely adsorbent used is a zeolite. Sulfide, phenol, and chromium (VI) derived from landfill leachate and domestic sewage are removed by zeliac, zeolites and activated carbon with the method of sequencing batch reactor (SBR) (Mojiri et al. 2015a). The results show that the addition of zeliac had a higher performance in removing $\mathrm{Cr}(\mathrm{VI})$.

Zeliac is a new adsorbent comprising a mixture of zeolite, activated carbon, lime, rice husk ash, and cement. In addition to the removal of heavy metals, zeliac can also eliminate other pollutants in wastewater. Zeliac were used as a filter on the tofu wastewater treatment. This study was aimed to analyze the utilization of $V$. zizanioides as a phytoremediator in the process of tofu wastewater treatment using zeliac.

\section{Materials and methods}

The research was conducted at the Laboratory of Environmental Research Center, Bogor Agricultural University, Indonesia. $V$. zizanioides and zeliac were used as a filter on the tofu wastewater treatment. $V$. zizanioides were selected based on the estimation of similar age, a height of $10-15 \mathrm{~cm}$. $V$. zizanioides were stored on the vessel with the size of $30 \times 20 \times 25 \mathrm{~cm}^{3}$ and acclimatized for 7 days. One container was composed of 4 clumps, and each clump had net weight of approximately $30 \mathrm{~g}$.

Each container was put into tofu liquid waste; then the treatment was tested in accordance with a predetermined combination of experiments. To maintain the position, Vetiver grass was placed on the pot with rockwool media. Pots with styrofoam holder were placed on the surface of tofu liquid waste. Figure 1 shows the experimental design using vetiver grass and zeliac. Zeliac was only used in the initial stages as a filter. Each container contained $2 \mathrm{~kg}$ of zeliac. Subsequently, the vetiver grass was planted for 3, 9 and 15 days. There were 13 treatment combinations of time (3, 9 and 15 days) and waste concentration (20, 40, 60\%). While, media maintenance volume was $20 \mathrm{~L}$.

Materials used for the manufacture of zeliac consisted of zeolites, activated carbon, lime, rice husk ash and cement which were milled (pass through a $300 \mathrm{~mm}$ sieve mesh). Furthermore, water was added and blended perfectly with the materials. The mixture was poured into a mold, left for $24 \mathrm{~h}$. Subsequently, it was removed from the mold and immersed in water for 3 days. Thereafter, the mixture was allowed to dry for 2 days and will be destroyed by itself (Mojiri et al. 2015b). Quality test of tofu wastewater was carried out on COD, BOD, TSS and turbidity, referring to the APHA (2005).

Specific growth rate (\%) was determined by the following equation (Kittiwongwattana and Supachai 2013).

$\mathrm{SGR}=\left(\frac{\ln X_{t}-\ln X_{0}}{t-t_{0}}\right) \times 100 \%$

where SGR is the specific growth rate $(\%), X_{0}$ is the initial wet weight at time $0(\mathrm{~g}), X_{\mathrm{t}}$ is the final wet weight at time $t, t_{0}$ is the initial time of observation (day), $t$ is the research duration (day).

The removal efficiency was calculated by the following formula (Khan et al. 2009):

$\%$ removal efficiency $=\frac{a-b}{a} \times 100$

where $a$ is the initial value of parameter, $b$ is the final values of parameter.

Response surface methodology was applied following central composite design with two factors: the levels of waste $(20,40,60 \%)$ and time $(3,9,15$ days). Before the experiment, a combination of treatment was determined using Design Expert 7.0 software, to obtain as many as 13 experimental designs. Surface response method was a set of mathematical and statistical techniques that are useful for

Fig. 1 System design

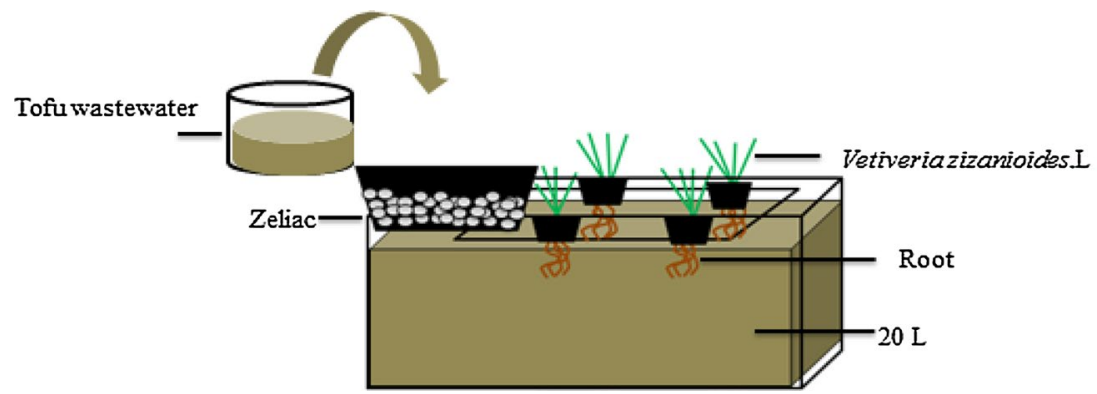


analyzing the problems in which some independent variables affect response variable and the ultimate goal is to optimize the response. The design model is as follows:

$Y=\beta_{0}+\sum_{i=1}^{k} \beta_{i} X_{i}+\sum_{i=1}^{k} \beta_{i i} X_{i}^{2}+\sum_{i=1, j=2}^{k-l, k} \beta_{i, j}, X_{i} X_{j}+\varepsilon$

where the response is shown by $Y ; X_{i}$ and $X_{j}$ are the factors; $\beta_{0}$ is an established coefficient; $\beta_{i}, \beta_{i j}$ and $\beta_{i i}$ display the interaction coefficients (linear, quadratic, and second-order terms, respectively), $k$ is number of analyzed parameters.

\section{Results and discussion}

Initial characteristics of tofu wastewater prior to treatment were chemical oxygen demand (COD) $(5759 \mathrm{mg} / \mathrm{L})$, biological oxygen demand (BOD) $(580 \mathrm{mg} / \mathrm{L})$, total suspended solid (TSS) $(552 \mathrm{mg} / \mathrm{L})$, and $\mathrm{pH}$ (3.9). This value was above the quality standard of the Government Regulation No. 05 of 2014 on Quality Standard of Industrial tofu wastewater namely BOD $(150 \mathrm{mg} / \mathrm{L})$, COD $(300 \mathrm{mg} / \mathrm{L})$, TSS (200 mg/L) and pH (6-9). Table 1 shows the removal response of COD, BOD, TSS, and the increase of $\mathrm{pH}$.

Figure $2 \mathrm{a}$ is a $3 \mathrm{D}$ surface response of COD reduction which shows that the concentration of the waste and time had a significant effect on the reduction of COD. The color difference contained in the chart shows the change in the value of COD reduction response. Removal percentage of COD increased from $22.90 \%$ (3 days and $40 \%$ waste) to $89.33 \%$ ( 15 days and $40 \%$ waste). Meanwhile removal percentage of BOD increased from 16.66\% (3 days and 40\% waste) to $86.73 \%$ (15 days and $40 \%$ waste) (Table 1). Dhas (2008) stated that the activated carbon and lime mixture are an alternative treatment to remove COD. In this study, zeliac contained activated carbon, rice husk ash, lime, cement, and zeolite. Such materials could effectively remove COD (Klimiuk and Kulikowska 2006). Zeliac was optimally capable of removing COD (Mojiri et al. 2015b). The ferric chloride in combination with synthetic cationic polymer (OxyflocFL-11) in the ratio of $250: 20 \mathrm{mg} \mathrm{L}(-1)$ resulted in very good removals of COD, BOD, and SS of 75.4, 79.8, and $96.0 \%$, respectively, with complete removal of odor, color and turbidity of waste manufacture of soya milk and tofu (Saryanaran et al. 2004). The combination of tofu-processing waste and digester sludge can be considered to be one of the most promising forms of organic waste for continuous $\mathrm{H}_{2}$ fermentative production (Kim and Lee 2010).

Removal percentage of BOD increased from $16.66 \%$ ( 3 days and $20 \%$ wastes) to $86.73 \%$ at 15 days and $60 \%$ wastes (Table 1). Surface response in 3D on BOD analysis is shown in Fig. 2b. High BOD indicates a high content of organic matter (for biologically biodegradable organic matter), requiring a sufficient amount of oxygen to decompose the organic material. If the organic content is too large while the oxygen level is inadequate, then there will be oxygen deficiency so it may not support the life of organisms that require oxygen. Microbial decomposition process is important for wastewater treatment. Microbial decomposition processes in wastewater treatment is indicated by the concentration of BOD. Biodegradable tofu waste can be processed with anaerobic method, yielding biogas and fluid, used as liquid fertilizer or can be mixed with the other biomass, such as vegetable waste, husks, etc. (Faisal et al. 2015).

Removal percentage of TSS sharply will affect an increase in turbidity. Turbidity is caused by suspended and dissolved organic and inorganic materials, as well as inorganic and organic materials in the form of plankton and other microorganisms. It will inhibit the process of penetration of sunlight into the waters and ultimately affect water photosynthesis.
Table 1 Treatment variable and water quality decrease percentage

\begin{tabular}{lclllll}
\hline Run & Time (days) & Waste $(\%)$ & COD $(\%)$ & BOD $(\%)$ & TSS $(\%)$ & pH \\
\hline 1 & 15 & 60 & 67.13 & 52.72 & 75.71 & 7.7 \\
2 & 3 & 40 & 22.90 & 19.38 & 65.16 & 6 \\
3 & 9 & 60 & 27.54 & 32.72 & 54.28 & 7.8 \\
4 & 9 & 40 & 52.16 & 36.73 & 78.08 & 7.7 \\
5 & 9 & 20 & 57.06 & 27.38 & 38.35 & 6 \\
6 & 9 & 40 & 48.19 & 20.40 & 64.04 & 7.7 \\
7 & 9 & 40 & 49.39 & 28.57 & 46.62 & 7.8 \\
8 & 15 & 20 & 79.47 & 61.90 & 75.68 & 7.5 \\
9 & 3 & 20 & 30.01 & 16.66 & 23.28 & 6 \\
10 & 9 & 40 & 48.19 & 28.57 & 43.82 & 7.7 \\
11 & 9 & 40 & 53.19 & 36.73 & 56.17 & 7.8 \\
12 & 15 & 40 & 89.33 & 86.73 & 82.30 & 7.5 \\
13 & 3 & 60 & 34.00 & 26.90 & 30.47 & 7 \\
\hline
\end{tabular}




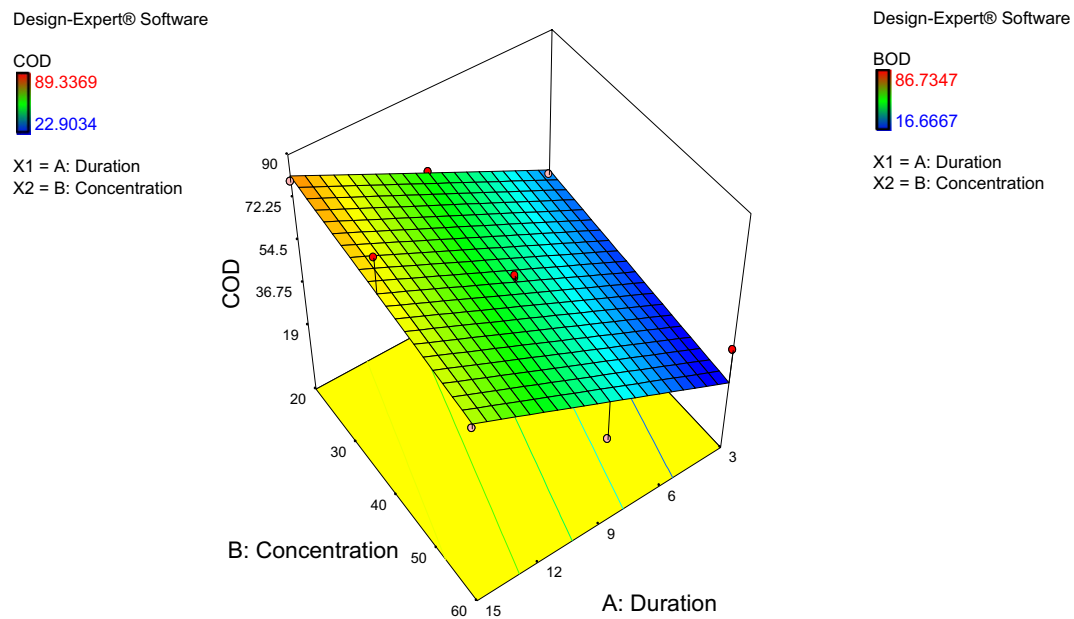

(a)

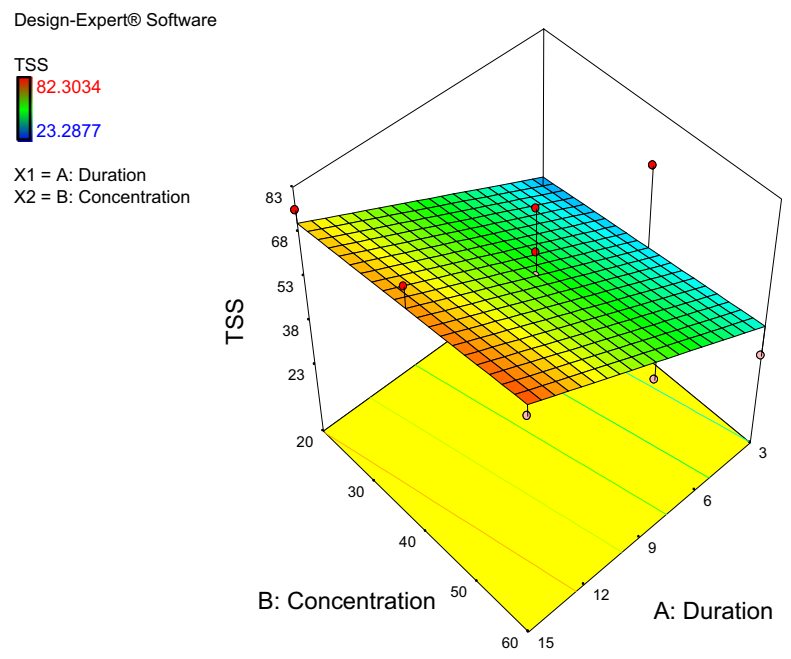

(c)

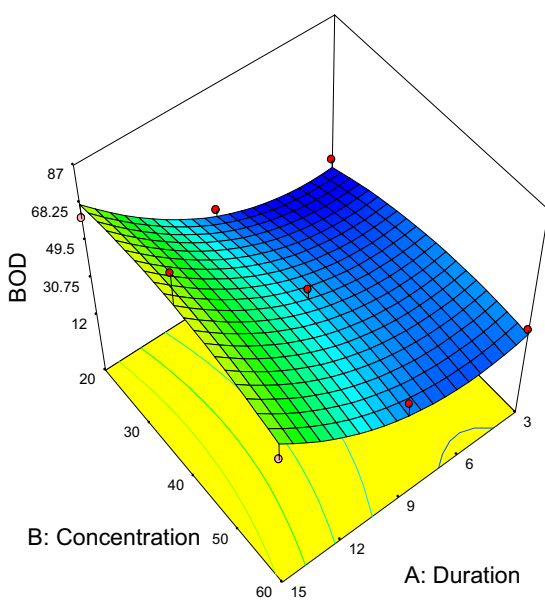

(b)

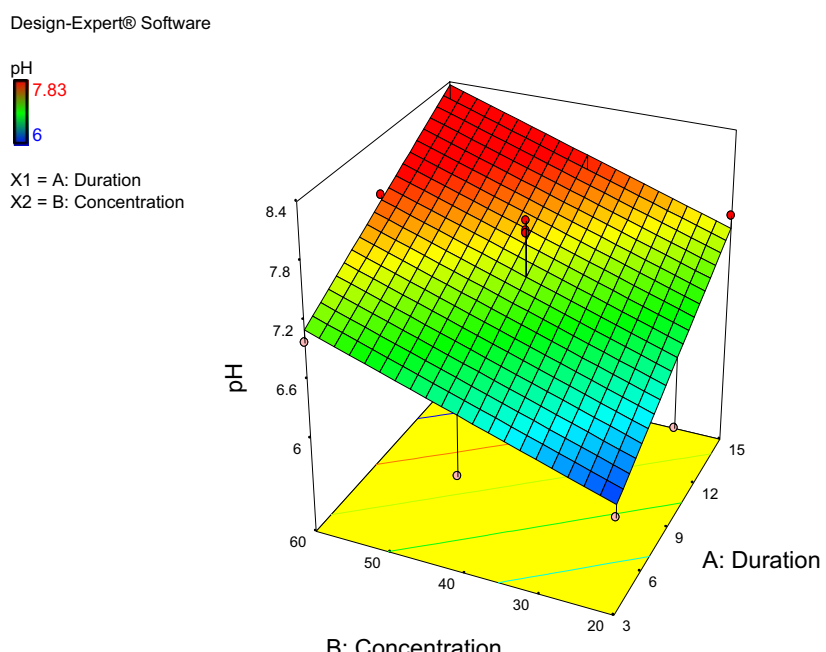

(d)

Fig. 2 Plot of 3D surface a COD, b BOD, $\mathbf{c}$ TSS, $\mathbf{d}$ pH

Removal percentage of TSS increased from $23.28 \%$ in 3 days and $20 \%$ wastes to $82.30 \%$ in 15 days and $60 \%$ wastes (Table 1). The 3D curve in Fig. 2c shows an increase in TSS. The concentration of waste and time had significant effect on the increase of TSS. The excessive value of TSS will affect the increase of turbidity which further hinders sunlight penetration into the water and ultimately influences photosynthesis of waters (Effendi 2003). Removal percentage of COD, BOD and TSS increased likely because of organic substance decomposition and the process of photosynthesis of plants that produce sufficient oxygen supply for microorganisms, rhizosphere to degrade waste more effectively. The process of photosynthesis in $V$. zizanioides allows the release of oxygen into the air and then diffused into the water around root (rhizosphere). The condition of rhizosphere zone rich in oxygen causes the development of aerobic bacteria to decompose the organic compounds, thereby decreasing the concentration of COD, BOD and TSS. Some of the organic compounds have been decomposed into other simpler compounds, then absorbed by plants for metabolic processes.

The $\mathrm{pH}$ of unprocessed tofu wastewater was 4.45 . This value was below the quality standard (6-9), since there were residual acids originating from the manufacturing process in the tofu wastewater. The $\mathrm{pH}$ value greatly affects the biochemical process of waters, because the decomposition of organic materials is faster at neutral and alkalis pH (Effendi 2003). According to Boyd (1982), the $\mathrm{pH}$ affects the rate of decomposition of organic matter. The $\mathrm{pH}$ during the observation ranged 6-7.8. 
Table 2 Vetiver root and stem length at the experiment

\begin{tabular}{llll}
\hline Run & Root $(\mathrm{cm})$ & Stem $(\mathrm{cm})$ & SGR $(\%)$ \\
\hline 1 & 16.75 & 27.5 & 0.024 \\
2 & 14.75 & 25.25 & 0.031 \\
3 & 15.75 & 33 & 0.023 \\
4 & 15 & 28.5 & 0.026 \\
5 & 15.47 & 27.25 & 0.037 \\
6 & 16.25 & 32,75 & 0.020 \\
7 & 15 & 28.25 & 0.023 \\
8 & 19.25 & 44.75 & 0.030 \\
9 & 14 & 23.75 & 0.070 \\
10 & 16.75 & 39.75 & 0.017 \\
11 & 14.75 & 37.75 & 0.025 \\
12 & 17 & 41.75 & 0.027 \\
13 & 12.25 & 22.75 & 0.022 \\
\hline
\end{tabular}

Vetiveria zizanioides root and stem length at the experiment as well as specific growth rate (SGR) is presented in Table 2. Low concentration of waste $(20 \%)$ related to high specific growth rate $(0.30-0.70)$. However, in general, vetiver could grow in all treatment concentrations. The process of wastewater treatment using aquatic plants occurred by filtration and absorption by the roots and stems of aquatic plants, ion exchange and absorption. Effendi et al. (2015a) stated that the observation of root growth of $V$. zizanioides was potential as a biofilter to absorb organic matter and nutrients (Delis et al. 2015; Effendi et al. 2015a).

The growth of vetiver could be seen from the specific growth rate (SGR) of roots and stems. Vetiver is potential as a biofilter to absorb organic material. Each treatment experienced an increase in the length of roots, stems and specific growth rate (SGR) of $V$. zizanioides (Table 2). The root system grew well with a length of $12.25-19.25 \mathrm{~cm}$. Longer roots will provide an opportunity to absorb nutrients (Effendi et al. 2017). V. zizanioides can also grow well. When the plant grows quickly, it needs greater nutrient uptake. The nutrient in the tofu wastewater derived from decomposition of organic material by microorganisms living naturally was absorbed by $V$. zizanioides and served as a source of new tissue formation.

The nutritional requirements are fulfilled from the decomposition of organic materials contained in the water, which will be used by autotrophic organisms, such as aquatic plants and phytoplankton (Effendi et al. 2015c).

Applications for the use of $V$. zizanioides on sewage purification with floating system showed normal growth in a river polluted by domestic waste for 4 weeks (Chunrong et al. 1998). Xuhui et al. (2002) also showed that $V$. zizanioides can survive for 10-12 months in wastewater with $\mathrm{COD}>400 \mathrm{mg} / \mathrm{L}$ and $\mathrm{BOD}>150 \mathrm{mg} / \mathrm{L}$.
Table 3 Response value at optimum condition

\begin{tabular}{lllllll}
\hline Factor & & & Responses & & \\
\cline { 1 - 2 } \cline { 5 - 7 } A (day) & B (\%) & & COD (\%) & BOD (\%) & TSS (\%) & pH \\
\hline 15 & 38.41 & 76 & 71.78 & 75.28 & 7.8 \\
\hline
\end{tabular}

$A$ time, $B$ waste concentration

Table 3 presents the response value at the optimum condition analyzed by Design Expert 7.0 with response surface methodology. Run 12 (15 days, waste 40\%) showed highest removal efficiency of COD $(89.33 \%)$, BOD $(86.73 \%)$ and TSS $(82.30 \%)$ in Table 1 . However, the removal efficiency of COD $(76 \%)$, BOD $(71.78 \%)$ and TSS $(75.28 \%)$ at the optimum condition obtained by Design Expert 7.0. Maximum is the highest limit, whilst optimum is the most favorable condition under specific sets of comparable circumstances determined by Design Expert 7.0.

\section{Conclusion}

The optimum condition of tofu wastewater treatment using vetiver ( $V$. zizanioides) and zeliac was 15 days and the waste concentration of $38.41 \%$ which could reduce the COD (76\%), BOD (71.78\%), TSS (75.28\%), and an increase in the $\mathrm{pH}(7.8)$.

Acknowledgements We would like to thank PPLH IPB for facilitating this research.

Open Access This article is distributed under the terms of the Creative Commons Attribution 4.0 International License (http://creativecomm ons.org/licenses/by/4.0/), which permits unrestricted use, distribution, and reproduction in any medium, provided you give appropriate credit to the original author(s) and the source, provide a link to the Creative Commons license, and indicate if changes were made.

\section{References}

American Public Health Association (APHA) (2005) Standard methods for the examination of water and wastewater. Water Pollution Control Federation, Baltimore

Bhatia SP, McGinty D, Letizia CS, Api AM (2008) Fragrance material review on vetiverol. Food Chem Toxicol 46:S297-S301

Boyd CE (1982) Water quality management for pond fish culture. Elsevier Scientific Publishing Company, Amsterdam, p 318

Chua LHC, Tan SBK, Sim CH, Goyal MK (2012) Treatment of baseflow from an urban catchment by a floating wetland system. Ecol Eng 49:170-180

Chunrong Z, Cong T, Huairnan C (1998) Preliminary study on purification of eutropic water with vetiver. In: Paper presented at the international vetiver grass technology workshop in Fuxhou, China

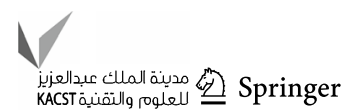


Danh LT, Truong P, Mammucari R, Tran T, Foster N (2009) Vetiver grass, Vetiveria zizanioides: a choice plant for phytoremediation of heavy metals and organic waster. Int J Phytoremediat 11:664-691

Datta R, Das P, Smith S, Punamiya P, Ramanthan DM, Reddy R, Sarkar D (2013) Phytoremediation potential of vetiver grass (Vetiveria zizanioides (L)) for tetracycline. Int J Phytoremediat 15:343-351

Delis PC, Effendi H, Krisanti M, Hariyadi S (2015) Treatment of aquaculture wastewater using Vetiveria zizanioides (Liliopsida, Poaceae). AACL 8:616-625

Dhas JPA (2008) Removal of COD and colour from textile wastewater using limestone and activated carbon (Msc thesis). University Sains Malaysia

Effendi H (2003) Assessing of water quality for water resources and environmental management. Kanisius, Jogjakarta (in Indonesian)

Effendi H, Delis PC, Krisanti M, Hariyadi S (2015a) The performance of nile tilapia (Oreochromis niloticus) and vetiver grass (Vetiveria zizanioides) concurrently cultivated in aquaponic system. Adv Environ Biol 9(24):382-388

Effendi H, Utomo BA, Darmawangsa GM (2015b) Phytoremediation of freshwater crayfish (Cherax quadricarinatus) culture wastewater with spinach (Ipomoea aquatica) in aquaponic system. AACL $8: 421-430$

Effendi H, Utomo BA, Darmawangsa GM, Hanafiah DA (2015c) Wastewater treatment of freshwater crayfish (Cherax quadricarinatus) culture with lettuce (Lactuca sativa). Int J Appl Environ Sci 10(1):409-420

Effendi H, Utomo BA, Darmawangsa GM, Sulaeman N (2015d) Combination of water spinach (Ipomea aquatica) and bacteria for freshwater cryfish red claw (Cherax quadricarinatus) culture wastewater treatment in aquaponic system. Adv Biol 6(3): 1072-1078

Effendi H, Wahyuningsih S, Wardiatno Y (2017) The use of nile tilapia (Oreochromis niloticus) cultivation waste water for the production of romaine lettuce (Lactuca sativa $\mathrm{L}$. var. longifolia) in water recirculation system. Appl Water Sci 7:3055-3063. https://doi. org/10.1007/s13201-016-0418-z

Faisal M, Mulana F, Gani A, Daimon H (2015) Physical and chemical properties of wastewater discharged from tofu industries in Banda Aceh City, Indonesia. Res J Pharm Biol Chem Sci 6(4):1053-1058

Indrayatie ER, Utomo WH, Handayanto E, Anderson CWN (2013) The use of vetiver (Vetiveria zizanioides $\mathrm{L}$.) for then remediation of wastewater discharged from tapioca factories. J Environ Waste Manag 12(1):1-16

Khan S, Ahmad I, Shah T, Rehman SH, Khaliq A (2009) Use of constructed wetland for the removal of heavy metals from industrial wastewater. J Environ Manag 90(11):3451-3457

Kim MS, Lee DY (2010) Fermentative hydrogen production from tofuprocessing waste and anaerobic digester sludge using microbial consortium. Bioresour Technol 101(2010):S48-S52
Kittiwongwattana C, Supachai V (2013) Effects of nutrient media on vegetative growth of Lemna minor and Landoltia punctata during in vitro and ex vitro cultivation. Maejo Int J Sci Technol 7(01):60-69

Klimiuk E, Kulikowska D (2006) The influence of hydraulic retention time and sludge age on the kinetics of nitrogen removal from leachate in SBR. Pol J Environ Stud 1(2):283-289

Mojiri A, Aziz H, Tajuddin M (2015a) Sulfide, phenols and chromium (VI) removal from landfill leachate and domestic wastewater by ZELIAC, zeolite and activated carbon augmented sequencing batch reactor (SBR). Res J Environ Toxicol 9(4):179-187. http s://doi.org/10.3923/rjet.2015.179.187

Mojiri A, Ziyang L, Tajuddin R, Farraji H, Alifar H (2015b) Cotreatment of landfill leachate and municipal wastewater using the ZELIAC/zeolite constructed wetland system. J Environ Manag 166:124-130. https://doi.org/10.1016/j.jenvman.2015.10.020

Phenrat T, Teeratitayangkul P, Prasertsung I, Parichatprecha R, Jitsangiam P, Chomchalow N, Wichai S (2017) Vetiver plantlets in aerated system degrade phenol in illegally dumped industrial wastewater by phytochemical and rhizomicrobial degradation. Environ Sci Pollut Res 24:13235-13246

Purwandari Y, Effendi H, Wardiatno Y (2017) The use of gourami (Osphronemus goramy) rearing wastewater for growing romaine lettuce (Lactuca sativa L. Var. longifolia) in aquaponic system. Asian J Microbiol Biotechnol Environ Sci 19(2):121-128

Saryanaran S, Venerkar AP, Ramakant (2004) Organic removals from highly proteinous wastewater from soya milk and tofu manufacturing plant. J Environ Sci Health 39(3):759-771

Tay JH (1990) Biological treatment of soya bean waste. J Water Sci Technol 22(9):141-147

Tripathy BK, Panda T, Mohanty RB (2014) Traditional artifacts from Bena grass [Chrysopogon zizanioides (L.) Roberty] (Poaceae) in Jajpur distric of Odisha, India. Indian J Tradit Knowl 13(4):771-777

Wahyuningsih S, Effendi H, Wardiatno Y (2015) Nitrogen removal of aquaculture wastewater in aquaponic recirculation system. AACL 8(4):491-499

Whitney D, Rossman A, Hayden N (2003) Evaluating an existing subsurface flow constructed wetland in Akumal, Mexico. Ecol Eng 20:105-111

Xuhui K, Lin W, Wang B, Lou F (2002) Study and vetiver's purification for wastewater from pig farm. Floricultural Research Institute of Guangdong Academy of Agriculture Sciences, Guangzhou

Publisher's Note Springer Nature remains neutral with regard to jurisdictional claims in published maps and institutional affiliations. 